\title{
VISUAL OUTCOME OF Nd-YAG LASER CAPSULOTOMY IN POSTERIOR CAPSULE OPACIFICATION
}

\author{
Gantela Sirisha1, Nallabantu Lakshmi Chowdary²
}

${ }^{1}$ Associate Professor, Department of Ophthalmology, NRI Medical College.

2 Professor and HOD, Department of Ophthalmology, NRI Medical College.

\section{ABSTRACT}

\section{BACKGROUND}

Cataract is the most common cause of blindness worldwide. Extracapsular Cataract Extraction (ECCE) with Posterior Chamber Intraocular Lens (PCIOL) implantation is the most popular method of cataract surgery. Posterior Capsule Opacification (PCO) is the post-operative complication, which occurs after cataract surgery. Incidence of PCO is about 18\%-50\%. PCO causes significant deterioration of visual acuity. Neodymium Yttrium Aluminium Garnet (Nd-YAG) laser posterior capsulotomy is the best procedure for the management of the PCO. The main aim of this study is to evaluate the visual outcome after YAG laser posterior capsulotomy.

\section{MATERIALS AND METHODS}

Retrospective analysis of 500 patients who presented with Posterior Capsule Opacification (PCO) after ECCE+PCIOL surgery with significant loss of visual acuity were included in the study. Postoperative period varied from 1 - 5 years; 500 patients underwent YAG laser capsulotomy. Visual acuity and intraocular pressure was recorded before and after the procedure.

\section{RESULTS}

The best corrected visual acuity of 6/9 - 6/6 was achieved in 328 patients (65.6\%) and 6/12 - 6/18 in 163 patients (32.6\%); $98 \%$ of the patients achieved improvement of visual acuity of more than 2 lines. Complications were noted in 22 patients (4.4\%). Raised IOP was recorded in 14 patients (2.8\%), IOL pitting was reported in 5 patients $(1 \%)$ and vitreous in anterior chamber was noted in 3 patients $(0.6 \%)$ after Nd-YAG laser capsulotomy.

\section{CONCLUSION}

Nd-YAG capsulotomy is the most effective and safe procedure in the management of PCO.

\section{KEYWORDS}

Neodymium Yttrium Aluminium Garnet (Nd-YAG) Laser Capsulotomy, Posterior Capsule Opacification (PCO) and Extracapsular Cataract Extraction (ECCE).

HOW TO CITE THIS ARTICLE: Sirisha G, Chowdary NL. Visual outcome of Nd-YAG laser capsulotomy in posterior capsule opacification. J. Evolution Med. Dent. Sci. 2016;5(29):1479-1482, DOI: 10.14260/jemds/2016/348

\section{INTRODUCTION}

Cataract is the main cause of curable blindness worldwide. Extracapsular Cataract Extraction with Posterior Chamber Intraocular Lens (ECCE+PCIOL) is the surgery of choice. Posterior Capsule Opacification (PCO) is most common complication, which occurs in about $18 \%-50 \%$ of patients undergoing ECCE+PCIOL surgery. ${ }^{1}$ PCO is the second most common cause of blindness. PCO usually occurs within two years after the surgery. It occurs in almost all cases following surgery for congenital cataract. The incidence of PCO declines with increasing age. ${ }^{2}$ PCO causes decreased vision, glare, monocular diplopia. ${ }^{3}$ and other symptoms similar to that of original cataract. It also decreases the field of view during therapeutic and diagnostic procedures.

PCO is caused by the proliferation and migration of residual lens epithelial cells, which causes fibrotic changes and wrinkling of the posterior capsule. 4 There are two clinically distinguishable morphological forms of PCO.

Financial or Other, Competing Interest: None.

Submission 19-02-2016, Peer Review 16-03-2016,

Acceptance 22-03-2016, Published 09-04-2016.

Corresponding Author:

Dr. Gantela Sirisha,

D. No. 26-36-207,

Ankamma Nagar

O line, Opp. SP Bungalow,

Guntur-522004.

E-mail: drsirishag@rediffmail.com

DOI: $10.14260 /$ jemds $/ 2016 / 348$
They are fibrosis-type PCO and Elschnig-pearl type PCO. Vacuolated (Pearl-type) PCO consists of proliferating swollen lens epithelial cells. They are commonly termed as Elschnig pearls. This causes significant visual loss. These are best visualized with silt lamp examination with retroillumination. ${ }^{5}$ Fibrotic type PCO is due to fibroblastic metaplasia of epithelial cells, which developed contractile qualities. Pearls at slit lamp and poor posterior pole visualization were all correlated with improvements in visual acuity and contrast sensitivity after capsulotomy. Amount of fibrosis visible at slit lamp and glare assessment were not correlated with vision improvements after laser. ${ }^{6}$

The incidence of PCO is reducing because of advanced surgical techniques and improvement of IOL designs and materials. $^{7}$

\begin{tabular}{|c|c|}
\hline \multicolumn{2}{|c|}{ Six Factors to Reduce PCO. } \\
\hline $\begin{array}{c}\text { Surgery-Related Factors } \\
\text { ("Capsular" Surgery) }\end{array}$ & $\begin{array}{c}\text { IOL-Related Factors } \\
\text { (“Ideal” IOL) }\end{array}$ \\
\hline $\begin{array}{c}\text { 1. Hydrodissection-enhanced } \\
\text { cortical clean-up. }\end{array}$ & $\begin{array}{c}\text { 1. Biocompatible IOL to } \\
\text { reduce stimulation of } \\
\text { cellular proliferation. }\end{array}$ \\
\hline 2. In-the-bag fixation of the IOL. & $\begin{array}{c}\text { 2. Maximal IOL optic- } \\
\text { posterior capsule contact, } \\
\text { angulated haptic. }\end{array}$ \\
\hline $\begin{array}{c}\text { 3. Small Continuous Curvilinear } \\
\text { Capsulorhexis (CCC) with edge on } \\
\text { IOL surface. }\end{array}$ & $\begin{array}{c}\text { 3. IOL optic geometry } \\
\text { square, truncated edge. }\end{array}$ \\
\hline
\end{tabular}

Nd-YAG laser posterior capsulotomy introduced a technique for closed eye, effective and relatively safe opening 
of opacified posterior capsule and laser capsulotomy became the standard care. ${ }^{9}$

Complications of Nd-YAG laser posterior capsulotomy include elevated intraocular pressure, Cystoid macular oedema (CME), IOL damage, retinal detachment, Propionibacterium acnes, Endophthalmitis, Iritis, Vitritis, Macular hole and Corneal oedema.10 The aetiology of CME following Nd-YAG laser capsulotomy.11 most likely involves movement of the vitreous cavity and vitreous damage, which results in the release of inflammatory mediators. Vitreoretinal traction caused by the procedure may also play a part. Delay in YAG laser by 6 months after cataract surgery will reduce the rate of CME.

\section{MATERIALS AND METHODS \\ Type of Study \\ Retrospective Study.}

\section{Source of Data}

500 patients who had visually significant PCO and underwent Nd-YAG laser Capsulotomy during the study period in the Department of Ophthalmology, NRI Medical College.

\section{Inclusion Criteria}

- Patients with regular follow-up and more than six months post-operative period.

- More than 2 lines decreased in the Best Corrected Visual Acuity (BCVA).

\section{Exclusion Criteria}

- Very thick PCO.

- Corneal Opacities.

- High Myopia.

- Retinal Pathologies.

- Active Intraocular Inflammation.

\section{METHODOLOGY}

After a thorough history taking, all the patients were evaluated clinically. Best corrected visual acuity was tested with Snellen's chart. Intraocular pressure was recorded. Silt lamp examination and fundus examination with direct ophthalmoscope was done to access the grade of PCO following Madurai PCO grading scale.

\section{Madurai PCO Grading Scale. ${ }^{12}$}

\begin{tabular}{|c|l|}
\hline $\begin{array}{c}\text { Level of } \\
\text { Severity }\end{array}$ & \multicolumn{1}{c|}{ Description } \\
\hline No PCO & $\begin{array}{l}\text { No evidence of Posterior Capsule Opacification } \\
\text { (PCO) seen before and after pupillary dilation to } \\
\text { a minimum of } 6 \mathrm{~mm} \text {. With a direct } \\
\text { ophthalmoscope a clear view of the optic disc, } \\
\text { blood vessels and the nerve fiber layer is } \\
\text { obtained. }\end{array}$ \\
\hline Grade I & $\begin{array}{l}\text { No central PCO is seen. PCO is seen only with } \\
\text { the pupil dilated to a minimum of } 6 \text { mm. With a } \\
\text { direct ophthalmoscope a clear view of the optic } \\
\text { disc, blood vessels and the nerve fiber layer is } \\
\text { obtained. }\end{array}$ \\
\hline Grade II & $\begin{array}{l}\text { PCO is present in the central visual axis, } \\
\text { detectable in an undilated pupil. With a direct } \\
\text { ophthalmoscope there is a mild obscuration of }\end{array}$ \\
\hline
\end{tabular}

\begin{tabular}{|c|l|}
\hline \multirow{3}{*}{ Grade III } & $\begin{array}{l}\text { fundus detail, in that the optic nerve head is } \\
\text { clearly seen but the retinal nerve fiber layer and } \\
\text { the blood vessels are not clearly seen. }\end{array}$ \\
\hline $\begin{array}{l}\text { PCO is present in the central visual axis with an } \\
\text { undilated pupil. With direct ophthalmoscope } \\
\text { there is a marked obscuration of fundus detail, } \\
\text { in that even the margins of the optic nerve head } \\
\text { are not clearly defined because of the PCO. }\end{array}$ \\
\hline
\end{tabular}

Pupil was dilated with 1\% Tropicamide eye drops prior to the laser capsulotomy. Q switched Nd-YAG laser with Helium Neon Beam for focusing was used.

\section{Posterior Capsulotomy Technique. ${ }^{13}$}

- $\quad$ Single pulse shots of minimum energy (If possible $1 \mathrm{~mL}$ ) are used.

- The energy and pulses were gradually increased according to the thickness of the PCO.

- Tension lines were cut across after identification.

- A cruciate opening was performed; first puncture was aimed at the visual axis.

- $\quad$ Residual tags were cleaned up.

- Free floating fragments were avoided.

The opening should equate approximately to the size of physiologically dilated pupil under scotopic conditions- this average 4-5 $\mathrm{mm}$ in the pseudophakic eye. Following procedure, Fluorometholone eye drops are instilled and advised to use thrice daily for one week and antiglaucoma therapy was advised when needed. Then the patients were reviewed for assessment of BCVA, IOP and for possible complications from one hour after the treatment and at the end of $1^{\text {st }}, 2^{\text {nd }}$ and $4^{\text {th }}$ week.

\section{RESULTS}

- Out of 500 patients who underwent Nd-YAG laser capsulotomy 246 (49.2\%) were males, 254 (50.8\%) were females (Table I).

- The mean interval between the cataract surgery and Nd-YAG laser capsulotomy was 1-5 years (Table II).

- $\quad$ Grading of the PCO (Table III).

- The no. of pulses required varied from 3-5 and energy levels ranged from $1 \mathrm{~mJ}-5 \mathrm{~mJ} /$ pulse (Table IV).

- $\quad$ The total energy delivered (Total Energy = Power $\mathrm{x}$ Total no. of Pulses) (Table V).

- Comparison of pre- and post-Nd-YAG laser visual acuity (distant vision) (Table VI).

- Comparison of pre- and post-laser near vision (Table VII).

- $\quad$ Complications of Nd-YAG laser (Table VIII).

- Rise of intraocular pressure after Nd-YAG laser (Table IX).

\begin{tabular}{|c|c|}
\hline Sex & No. of Cases (\%) \\
\hline Male & $246(49.2 \%)$ \\
\hline Female & $254(50.8 \%)$ \\
\hline Total & 500 (100\%) \\
\hline \multicolumn{2}{|c|}{ Table 1: Gender Distribution } \\
\hline
\end{tabular}




\begin{tabular}{|c|c|}
\hline Time Interval (Years) & No. of Cases (\%) \\
\hline 1 & $256(51.2 \%)$ \\
\hline 2 & $142(28.4 \%)$ \\
\hline 3 & $63(12.6 \%)$ \\
\hline 4 & $19(3.8 \%)$ \\
\hline 5 & $20(4.0 \%)$ \\
\hline Total & $\mathbf{5 0 0}(100 \%)$ \\
\hline $\begin{array}{c}\text { Table 2: Time Interval between PCO Development and Nd- } \\
\text { YAG Laser Treatment }\end{array}$ \\
\hline
\end{tabular}

\begin{tabular}{|c|c|}
\hline Energy Level (mJ) & No. of Cases \\
\hline 1 & $47(9.4 \%)$ \\
\hline 2 & $265(53.0 \%)$ \\
\hline 3 & $172(34.4 \%)$ \\
\hline 4 & $9(1.8 \%)$ \\
\hline 5 & $7(1.4 \%)$ \\
\hline Total & $\mathbf{5 0 0}(\mathbf{1 0 0} \%)$ \\
\hline Table 3: Summary of Energy Level used for Capsulotomy \\
\hline
\end{tabular}

\begin{tabular}{|c|c|}
\hline Type of PCO & No. of Cases \\
\hline Mild & $96(19.2 \%)$ \\
\hline Moderate & $362(72.4 \%)$ \\
\hline Severe & $42(8.4 \%)$ \\
\hline Total & $\mathbf{5 0 0}(100 \%)$ \\
\hline \multicolumn{2}{|c|}{ Table 4: Grading of PCO } \\
\hline
\end{tabular}

\begin{tabular}{|c|c|}
\hline Energy Level (mJ) & No. of Cases \\
\hline $10-20$ & $264(52.8 \%)$ \\
\hline $21-30$ & $148(29.6 \%)$ \\
\hline $31-40$ & $75(15.0 \%)$ \\
\hline $41-50$ & $4(0.8 \%)$ \\
\hline $51-60$ & $4(0.8 \%)$ \\
\hline $61-70$ & $1(0.2 \%)$ \\
\hline $71-80$ & $1(0.2 \%)$ \\
\hline $81-90$ & $2(0.4 \%)$ \\
\hline 91-100 & $1(0.2 \%)$ \\
\hline \multicolumn{2}{|c|}{ Total } \\
\hline \multicolumn{2}{|c|}{ Capsule 5: Summary of Total Energy Level used for } \\
\hline
\end{tabular}

\begin{tabular}{|c|c|c|}
\hline Visual Acuity & Pre Laser (\%) & Post Laser (\%) \\
\hline CF - 6/60 & $64(12.8 \%)$ & $2(0.4 \%)$ \\
\hline $6 / 36-6 / 24$ & $128(25.6 \%)$ & $7(1.4 \%)$ \\
\hline $6 / 18-6 / 12$ & $266(53.2 \%)$ & $163(32.6 \%)$ \\
\hline $6 / 9-6 / 6$ & $42(8.4 \%)$ & $328(65.6 \%)$ \\
\hline Total & 500 (100\%) & $\mathbf{5 0 0}(100 \%)$ \\
\hline \multicolumn{3}{|c|}{ Table 6: Comparison of Pre and Post YAG Laser } \\
Visual Acuity \\
\hline
\end{tabular}

\begin{tabular}{|c|c|c|}
\hline Visual Acuity & Pre Laser (\%) & Post Laser (\%) \\
\hline $\mathrm{N} 5$ & $0(0.0 \%)$ & $65(13.0 \%)$ \\
\hline $\mathrm{N} 6$ & $0(0.0 \%)$ & $269(53.8 \%)$ \\
\hline $\mathrm{N} 8$ & $97(19.4 \%)$ & $126(25.2 \%)$ \\
\hline $\mathrm{N} 10$ & $342(68.4 \%)$ & $30(6.0 \%)$ \\
\hline$<\mathrm{N} 10$ & $61(12.2 \%)$ & $10(2.0 \%)$ \\
\hline Total & $\mathbf{5 0 0}(100 \%)$ & $\mathbf{5 0 0}(100 \%)$ \\
\hline \multicolumn{3}{|c|}{ Table 7: Comparison of Pre and Post YAG } \\
Laser Near Vision \\
\hline
\end{tabular}

\begin{tabular}{|c|c|}
\hline Type & No. of Cases \\
\hline Raised IOP & $14(2.8 \%)$ \\
\hline IOL Pitting & $5(1.0 \%)$ \\
\hline Vitreous in AC & $3(0.6 \%)$ \\
\hline CME & - \\
\hline Total & $\mathbf{2 2 ~ ( 4 . 4 \% )}$ \\
\hline \multicolumn{2}{|c|}{ Table 8: Complication of Nd-YAG Laser } \\
\hline
\end{tabular}

\begin{tabular}{|c|c|c|c|}
\hline Energy Used & $\begin{array}{c}\text { No. of Eyes } \\
(\%)\end{array}$ & $\begin{array}{c}20 \mathrm{~mm}-30 \\
\mathrm{~mm}\end{array}$ & $>30 \mathrm{~mm}$ \\
\hline $10-20$ & $264(52.8 \%)$ & $0(0.0 \%)$ & $0(0.0 \%)$ \\
\hline $21-30$ & $148(29.6 \%)$ & $0(0.0 \%)$ & $0(0.0 \%)$ \\
\hline $31-40$ & $75(15.0 \%)$ & $4(0.8 \%)$ & $0(0.0 \%)$ \\
\hline $41-50$ & $4(0.8 \%)$ & $1(0.2 \%)$ & $0(0.0 \%)$ \\
\hline $51-60$ & $4(0.8 \%)$ & $2(0.4 \%)$ & $0(0.0 \%)$ \\
\hline $61-70$ & $1(0.2 \%)$ & $1(0.2 \%)$ & $0(0.0 \%)$ \\
\hline $71-80$ & $1(0.2 \%)$ & $1(0.2 \%)$ & $0(0.0 \%)$ \\
\hline $81-90$ & $2(0.4 \%)$ & $2(0.4 \%)$ & $1(0.2 \%)$ \\
\hline $91-100$ & $1(0.2 \%)$ & $1(0.2 \%)$ & $1(0.2 \%)$ \\
\hline Total & $500(100 \%)$ & $12(2.4 \%)$ & $\begin{array}{c}2 \\
(0.4 \%)\end{array}$ \\
\hline
\end{tabular}

\section{DISCUSSION}

Nd-YAG laser capsulotomy is a frequently performed procedure after ECCE surgery, because PCO.14 is the most common complication after cataract surgery. In the study of 500 cases, the time interval between cataract surgery and $\mathrm{Nd}$ YAG laser capsulotomy was around 1-5 years. Significant visual improvement of more than 2 lines is seen in $98 \%$ of cases after Nd-YAG laser capsulotomy. In our study, the Best Corrected Visual Acuity (BCVA) of 6/9 - 6/6 was achieved in 328 patients $(65.6 \%)$. BCVA of $6 / 18-6 / 12$ was achieved in 163 patients $(32.6 \%)$ (Table VI), whereas only 9 patients (1.8\%) did not have significant improvement of visual acuity, because of pre-existing fundus pathology which was not detected due to thick PCO.

The complications which occurred in this study are Raised IOP, IOL Pitting and Rupture of the Anterior Vitreous Face.

\section{RAISED IOP}

Raised IOP has occurred in 14 eyes (2.8\%). IOP elevation is very mild and transient. The causes for raised IOP are deposition of capsular debris in the trabecular meshwork, inflammatory swelling of the ciliary body or iris root associated with angle closure, liquefied vitreous and shock wave damage to the trabecular meshwork. IOP was raised in patients $14(2.8 \%) ; 12(2.4 \%)$ patients had IOP between 20 $30 \mathrm{mmHg} ; 2(0.4 \%)$ patients had pressure IOP more than 30 mmHg. IOP was controlled with anti-glaucoma medication. Raised IOP was noted when higher pulses energies were used. Normal IOP was reached within 3 days with topical beta blockers $(0.5 \%$ Timolol maleate eye drops) twice daily.

\section{IOL Damage (IOL Pitting)}

IOL Pitting has occurred in 5 eyes (1\%) of cases. Proper focusing of the aiming beam and low energy levels will prevent damage to the IOL. Few laser marks on the IOL do not alter visual function or impair ocular tolerance of the IOL.

\section{Rupture of the Anterior Vitreous Face (AVF)}

Rupture of AVF occurred in 3 cases (0.6\%). Forward displacement of vitreous in anterior chamber is seen. This is due to liquefied vitreous resulting in vitreous traction and lead to retinal breaks and detachments.

\section{CONCLUSION}

Posterior Capsule Opacification (PCO) is the most common visually disabling consequence of modern cataract surgery and has important medical, social and economic implications. At present, the most effective treatment of PCO is Nd:YAG 
laser capsulotomy. Nd:YAG laser capsulotomy treatment is an effective technique to improve visual impairment caused by PCO. It has very few complications when accurate focusing and low energy levels are used.

\section{REFERENCES}

1. Schaumberg DA, Dana MR, Christen WG, et al. A systematic overview of the incidence of posterior capsule opacification. Ophthalmology 1998;105(7):1213-1221.

2. Roger F Steinert. Nd-YAG laser posterior capsulotomy. America Academy of ophthalmology 2013.

3. Brad Bowling. Kanski's clinical ophthalmology. A systemic approach. Elsevier 2016;8 th edition:p 293.

4. Apple DJ, Solomon KD, Tetz MR, et al. Posterior capsular opacification. Survey of ophthalmology 1992;37(2):73116.

5. William R Meacock, David J Spalton, James Boyce, et al. The effect of posterior capsule opacification on visual function. Clinical and epidemiologic research. Investigative Ophthalmology \& Visual science 2003;44(11):4665-4669.

6. Tariq M Aslam, Niall Patton. Methods of assessment of patients for Nd-YAG laser capsulotomy that correlate with final visual improvement. BMC Ophthalmology 2004;4:13.

7. Suresh K Pandey, David J Apple, Werner L, et al. Posterior capsule opacification: a review of the aetiopathogenesis, experimental and clinical studies and factors for prevention. Indian Journal of Ophthalmology 2004;52(2):99-112.
8. Hollick EJ, Spalton DJ, Ursell PG, et al. Lens epithelial cell regression on the posterior capsule with different intraocular lens materials. $\mathrm{Br} \mathrm{J}$ Ophthalmology 1998;82(10):1182-1188.

9. Dewey Steven. Posterior capsule opacification. Current Opinion in Ophthalmology 2006;17(1):45-53.

10. Roger F Steinert, Carmen A Puliafito, Sanjiv R Kumar, et al. Cystoid macular edema, retinal detachment, and glaucoma after Nd:YAG laser posterior capsulotomy. American Journal of Ophthalmology 1991;112(4):373380.

11. Arlo C Terry, Walter J Stark, Edward Maumenee A, et al. Neodymium-yag laser for posterior capsulotomy. American Journal of Ophthalmology 1983;96(6)716720.

12. Prajna NV, Ellwein LB, Selvaraj $S$, et al. The madurai intra ocular lens study IV posterior capsular opacification. American journal of ophthalmology 2000;130(3):304-309.

13. Ken Hayashi, Hideyuki Hayashi, Fuminori Nakao, et al. Correlation between posterior capsule opacification and visual function before and after neodymium: YAG laser posterior capsulotomy. American Journal of Ophthalmology 2003;136(4):720-726.

14. Javit JC, Tielsch JM, Canner JK. National outcomes of cataract extraction; increased retinal complication associated with nd: YAG capsulotomy. Ophthalmology 1992;99(10):1487-1497. 